\title{
Extent of Propionate Metabolism During Absorption from the Bovine Ruminoreticulum
}

\author{
By EDGAR WEIGAND*, JERRY W. YOUNG and A. DARE McGILLIARD \\ Department of Animal Science, Iowa State University, Ames, Iowa 50010, U.S.A.
}

(Received 13 August 1971)

\begin{abstract}
1. Solutions containing acetate, $\left[2-{ }^{14} \mathrm{C}\right]$ propionate and butyrate were placed into the ruminoreticulum of calves to measure the extent to which propionate is metabolized by ruminoreticulum epithelium. In response to five different combinations of $\mathrm{pH}$ and total volatile fatty acid concentrations, propionate absorption rates ranged from 89 to $341 \mathrm{mmol} / \mathrm{h}$. 2. The extent of propionate conversion into lactate, calculated from both concentration and specific radioactivity in portal and arterial blood, averaged 4.9 (range 2.5-9.1)\%. 3. Circulating glucose synthesized from propionate had a higher specific radioactivity than arterial lactate and was converted into lactate by gastrointestinal tissues. Thus conversion of propionate into lactate was overestimated but was corrected to average $2.3(1.0-4.6) \%$. 4. The estimates of propionate conversion into lactate were negatively correlated with its rate of absorption.
\end{abstract}

Propionate, a major volatile fatty acid produced from dietary carbohydrates by microbial fermentation in the ruminoreticulum and absorbed into the portal circulation, is a key precursor for glucose synthesis in the liver of ruminants. Leng et al. (1967) estimated that, in sheep, propionate was converted extensively into lactate before it was synthesized into glucose. They suggested that the rumen epithelium was the site of this conversion of propionate into lactate. This idea is supported by studies in vitro showing that lactate accumulates as the major metabolite during incubations of rumen epithelium with propionate (Pennington \& Sutherland, 1956; Taylor \& Ramsey, 1965; Weigand et al., 1967). We conducted a series of experiments to measure quantitatively the extent to which propionate is converted into lactate during absorption from the bovine ruminoreticulum.

\section{Experimental}

\section{Materials}

Polyethylene glycol (average mol.wt. 3000-3700) and gum arabic were obtained from Matheson, Coleman and Bell (Elk Grove Village, Ill., U.S.A.). Lactate dehydrogenase was from Boehringer Mannheim Corp. (New York, N.Y., U.S.A.) and $\beta$-NAD ${ }^{+}$, grade III, from Sigma Chemical Company (St Louis, Mo., U.S.A.). All reagents were analytical grade. [2-14 C]Propionate (Volk Radiochemical, Burbank, Calif., U.S.A.) was checked for purity by partition chromatography (Ramsey, 1963).

* Present address: Institut für Tierernährung, Technische Universität München, 805 Freising-Weihenstephan, West Germany.

\section{Animals}

Three male Holstein calves weighing 225-250kg were fed about $2 \mathrm{~kg}$ of concentrate/day (65\% corn, $21 \%$ oats, $12 \%$ soya-bean oil meal, $2 \%$ minerals) and alfalfa or grass hay ad libitum. At least 4 weeks before the first experiment with an animal, a rumen fistula $(10 \mathrm{~cm}$ internal diam.) was established (Dougherty, 1955). All further surgical preparations were performed during a later operation, at least 2 weeks before the first experiment. An arterial catheter was established in the thoracic aorta (Olsen et al., 1967). The portal vein of calf 72 was catheterized (Conner \& Fries, 1960), but a hydraulic needle was implanted on to the portal vein of calves 10 and 84 (McGilliard, 1971). A re-entrant cannula, similar to the one described by Ash (1962) for sheep, was put into the duodenum about $10 \mathrm{~cm}$ distal to the pylorus (Brown et al., 1968).

\section{Test solutions}

Five solutions were prepared containing acetate, propionate and butyrate in a molar proportion of 60:25:15 and varying only in $\mathrm{pH}$ and total volatile fatty acid concentration (Table 1). The $\mathrm{pH}$ was adjusted with a mixture of $\mathrm{NaOH}-\mathrm{KOH}$ (molar ratio 29:1) to approximate the $\left[\mathrm{Na}^{+}\right] /\left[\mathrm{K}^{+}\right]$ratio in plasma (Guyton, 1966). All volatile fatty acid solutions contained $300 \mathrm{mg}$ of polyethylene glycol $/ 100 \mathrm{ml}$ as a volume marker. Propionate was labelled by adding about $0.5 \mathrm{mCi}$ of $\left[2-{ }^{14} \mathrm{C}\right]$ propionate. 
Table 1. Rate of propionate absorption from the ruminoreticulum of calves

Test solutions containing acetate, $\left[2-{ }^{14} \mathrm{C}\right]$ propionate and butyrate in the molar proportion of $60: 25: 15$ and varying in $\mathrm{pH}$ and total volatile fatty acid concentration were placed into the emptied ruminoreticulum of three rumen-fistulated calves in ten experiments in vivo. Total concentration includes all three volatile fatty acids. The rate of propionate absorption was taken as the decrease of propionate in the test solution relative to the concentrations of polyethylene glycol.

\begin{tabular}{|c|c|c|c|c|}
\hline \multicolumn{2}{|c|}{ Test solution } & & & \multirow[b]{2}{*}{$\begin{array}{c}\text { Rate of propionate } \\
\text { absorption } \\
\text { (mmol/h) }\end{array}$} \\
\hline pH & $\begin{array}{l}\text { Total volatile } \\
\text { fatty acid concn. } \\
(\mathrm{mmol} / \mathrm{l})\end{array}$ & Expt. no. & Calf no. & \\
\hline 7.2 & 150 & $\begin{array}{l}2 \\
3\end{array}$ & $\begin{array}{l}72 \\
84\end{array}$ & $\begin{array}{r}163 \\
218 \\
\text { Average } 191\end{array}$ \\
\hline 4.8 & 150 & $\begin{array}{l}1 \\
4\end{array}$ & $\begin{array}{l}72 \\
84\end{array}$ & $\begin{array}{r}288 \\
341 \\
\text { Average } 315\end{array}$ \\
\hline 6.0 & 75 & $\begin{array}{l}6 \\
8\end{array}$ & $\begin{array}{l}84 \\
10\end{array}$ & $\begin{array}{r}101 \\
89 \\
\text { Average } \quad 95\end{array}$ \\
\hline 6.0 & 150 & $\begin{array}{l}5 \\
9\end{array}$ & $\begin{array}{l}84 \\
10\end{array}$ & $\begin{array}{r}233 \\
158 \\
\text { Average } 196\end{array}$ \\
\hline 6.0 & 225 & $\begin{array}{r}7 \\
10\end{array}$ & $\begin{array}{l}84 \\
10\end{array}$ & $\begin{array}{r}314 \\
156 \\
\text { Average } 235\end{array}$ \\
\hline
\end{tabular}

\section{Experimental procedures}

About $1 \mathrm{~h}$ before each experiment, the ruminoreticulum was emptied through the fistula and washed with warm water. To prevent loss of absorptive ability (Sutton et al., 1963), about 7 litres of non-radioactive volatile fatty acid solution at $39^{\circ} \mathrm{C}$ was added immediately to the ruminoreticulum. The re-entrant duodenal cannula was disconnected, and digesta passing from the abomasum were collected during the experiment.

When preparations were completed, the non-radioactive volatile fatty acid solution was removed. From 18 litres of radioactive test solution at $39^{\circ} \mathrm{C}$, about 4 litres was placed in a container on a temperaturecontrolled stirrer, and the remainder was poured into the ruminoreticulum. During each experiment of 45 min duration, solutions in the container and the ruminoreticulum were cross-circulated at about 2 litres/min. The $\mathrm{pH}$ of the test solution in the container was monitored and maintained by the addition of $18 \%(\mathrm{v} / \mathrm{v}) \mathrm{HCl}$.

Blood samples of at least $76 \mathrm{ml}$ were withdrawn simultaneously through the portal and arterial catheters at $5,10,15,20,30$ and $45 \mathrm{~min}$ after propionate administration. One additional blood sample was obtained at the end for determination of analytical recoveries of blood constituents.

\section{Analyses on the test solutions}

Polyethylene glycol and volatile fatty acid concentrations were determined on test solution taken before and after experiments. Polyethylene glycol was determined as described by Malawer \& Powell (1967) except that protein-free solutions were prepared by consecutively adding and mixing $5 \mathrm{vol}$. of $1.2 \%(\mathrm{w} / \mathrm{v}) \quad \mathrm{BaCl}_{2}, 2 \mathrm{H}_{2} \mathrm{O}, 2 \mathrm{vol}$. of $0.15 \mathrm{M}-$ $\mathrm{Ba}(\mathrm{OH})_{2}, 8 \mathrm{H}_{2} \mathrm{O}$ and 2 vol. of $5 \%(\mathrm{w} / \mathrm{v}) \mathrm{ZnSO}_{4}, 7 \mathrm{H}_{2} \mathrm{O}$. The precipitate was removed by centrifugation at $8000 \mathrm{~g}$ for $15 \mathrm{~min}$. The emulsifying agent to stabilize the polyethylene glycol was gum arabic $(2 \mathrm{mg} / \mathrm{l})$. Standard solutions of $150-500 \mathrm{mg}$ of polyethylene glycol $/ 100 \mathrm{ml}$ were included in each analysis.

For volatile fatty acid analysis, $2 \mathrm{ml}$ of an isovalerate internal standard $(50$ or $100 \mathrm{mmol} / 1)$ was added to $10 \mathrm{ml}$ of test solution. Then $2 \mathrm{ml}$ of about $12 \%(w / v)$ metaphosphoric acid was added to adjust the $\mathrm{pH}$ to about 2 . After filtration, the samples were kept at $-20^{\circ} \mathrm{C}$ until analysis. Volatile fatty acid concentrations were determined by g.l.c. with a model 600 Aerograph $\mathrm{Hy}-\mathrm{Fi}$ with a hydrogen flameionization detector. A $2 \mathrm{~m}$ column was packed with $15 \%$ FFAP (trade name for free fatty acid phase, Wilkens Instrument and Research Inc., Walnut Creek, Calif., U.S.A.) coated on 60-80 mesh acid-washed Chromosorb W (Applied Science Labs., State College, 
Pa., U.S.A.). $\mathrm{N}_{2}$ was the carrier gas $[18 \mathrm{ml} / \mathrm{min}$ at $0.1 \mathrm{MN} / \mathrm{m}^{2}$ (1 atm)]. The injection temperature was $225^{\circ} \mathrm{C}$, and the column temperature was $145-150^{\circ} \mathrm{C}$. A volatile fatty acid standard was used to establish the relative detector response between internal standard and other volatile fatty acids.

\section{Deproteinization of blood}

Immediately after blood was withdrawn into heparinized syringes, $75 \mathrm{ml}$ was transferred into flasks containing $500 \mathrm{ml}$ of water, $25 \mathrm{ml}$ of an isovalerate standard, and $75 \mathrm{ml}$ of $0.33 \mathrm{M}-\mathrm{H}_{2} \mathrm{SO}_{4}$. After each experiment, the protein was precipitated by the addition of $75 \mathrm{ml}$ of $10 \%(\mathrm{w} / \mathrm{v}) \mathrm{Na}_{2} \mathrm{WO}_{4}, 2 \mathrm{H}_{2} \mathrm{O}$ (Folin \& Wu, 1919). Next, the samples were centrifuged at $8000 \mathrm{~g}$ for $15 \mathrm{~min}$. The supernatants were filtered and divided into portions for various analyses.

\section{Radioactivity in blood}

Samples $(1 \mathrm{ml})$ of protein-free blood filtrates were pipetted into counting vials. One drop of $1 \mathrm{M}$ $\mathrm{KOH}$ and $15 \mathrm{ml}$ of scintillator containing thixotropic gel powder (Casjens \& Morris, 1965) were added and mixed. The samples were counted for radioactivity at 64-66\% efficiency in a Packard model 3002 Tri-Carb liquid-scintillation spectrometer. Radioactivity was expressed as d.p.m./ml of blood by using $\left[{ }^{14} \mathrm{C}\right]$ toluene as internal standard.

\section{Concentrations of blood constituents}

Blood propionate concentration was also determined by g.l.c. with conditions the same as in the volatile fatty acid analysis of test solutions and by using isovalerate, added before blood deproteinization, as an internal standard. About $150 \mathrm{ml}$ of filtrate was made alkaline, freeze-dried, and stored at $4^{\circ} \mathrm{C}$. Before analysis for volatile fatty acids the dry residues were dissolved in $2-4 \mathrm{ml}$ of approx. $1.7 \%$ (w/v) metaphosphoric acid and 1-3 drops of $9 \mathrm{M}-$ $\mathrm{H}_{2} \mathrm{SO}_{4}$.

L-( + -Lactate content in blood was determined enzymically (Hohorst, 1965) on protein-free filtrates and corrected for recovery, which averaged $94.1 \%$ $( \pm 1.7$ s.E.M.) for the ten experiments. Glucose concentrations were determined by the enzymic glucose oxidase method (Worthington Biochemical Corp., Freehold, N.J., U.S.A.), and the specific radioactivity of glucose was determined by isolating the penta-acetate derivative and counting in toluene (Jones, 1965). Haemoglobin concentrations of portal arterial blood were determined (van Kampen \& Zijlstra, 1961) to measure haemodilution or haemoconcentration.

\section{Specific radioactivity of propionate and lactate in blood}

About $350 \mathrm{ml}$ of protein-free blood filtrates was made alkaline, freeze-dried and stored at $4^{\circ} \mathrm{C}$. Organic acids in the blood were extracted with ether and partitioned on silicic acid columns (Ramsey, 1963). After analysis of a few samples from expts. 1 and 2 the main radioactivity was found to be associated only with propionic acid and lactic acid; the columns were therefore not continued beyond the elution of lactic acid. The solvent 2-methylpropan2-ol-chloroform $(1: 24, \mathrm{v} / \mathrm{v})$, replacing the 1:19(v/v) solvent mixture, gave good separation of lactic acid from $\beta$-hydroxybutyric acid.

Eluents were collected in $10 \mathrm{ml}$ fractions into $20 \mathrm{ml}$ scintillation vials. After addition of $0.2 \mathrm{ml}$ of ethanolic $0.1 \%(w / v)$ thymolphthalein to each fraction, the acids were titrated with standardized ethanolic $\mathrm{KOH}$ (about $0.01 \mathrm{M}$ ) while $\mathrm{N}_{2}$ was bubbled through the solvent. After addition of more ethanolic $\mathrm{KOH}$, the solvent was evaporated. A portion $(1 \mathrm{ml})$ of $1 \mathrm{M}$-acetic acid and $10 \mathrm{ml}$ of xylene-dioxan-Cellosolve scintillator (Bruno \& Christian, 1961) were added to the dry vials, and the fractions were counted for radioactivity. Titration values were corrected for base-line values and recorded radioactivities for background and counting efficiency.

\section{Statistical analysis}

Results were statistically tested as described by Steel \& Torrie (1960). Calf 84 was the only animal to receive all five test solutions. Because calf 72 died after the second experiment it was necessary to split the ten experiments into two segments, one with $\mathrm{pH}$ of the test solution as the variable (Expts. 1-4; calves 72 and 84) and the other with volatile fatty acid concentration as the variable (Expts. 5-10; calves 10 and 84).

\section{Results and Discussion}

\section{Rates of propionate absorption}

The molar proportion of acetate, propionate and butyrate, total volatile fatty acid concentrations and $\mathrm{pH}$ of the test solutions were similar to those normally found in the ruminoreticulum of animals fed on a wide range of concentrate-roughage diets. Different combinations of $\mathrm{pH}$ and total volatile fatty acid concentration were chosen to cause variations in absorption rates of volatile fatty acids from the ruminoreticulum. Only the absorption rates of propionate are presented (Table 1). As the $\mathrm{pH}$ of the test solutions was lowered from 7.2 to 4.8 , absorption rates of propionate increased from an average of 191 to $315 \mathrm{mmol} / \mathrm{h}$. Propionate was also absorbed faster with the increase in total volatile fatty acid concen- 
tration from 75 to 150 to $225 \mathrm{mmol} / \mathrm{l}$. The total volatile fatty acid concentrations would include $18.75,37.50$ and $56.25 \mathrm{mmol} / 1$ of propionate respectively. In Expt. 10 the absorption rate was relatively low, evidently because the calf had lost most of its rumen digesta the night before the experiment.

\section{Concentration and distribution of propionate and lactate in blood}

Portal-arterial differences in haemoglobin were negligible and within the range of error of analytical determination. Consequently, no correction was applied for haemodilution or haemoconcentration of portal blood. Concentrations of propionate and lactate at each sampling time were always higher in portal than in arterial blood. Mean portal concentrations and mean portal-arterial differences are summarized in Table 2. At pH4.8, the portal values and also the portal-arterial differences of propionate were about twice as high as at pH 7.2. With solutions having volatile fatty acid concentrations of 75,150 and $225 \mathrm{mmol} / 1$, the portal concentrations of propionate averaged 390,453 and $572 \mu \mathrm{mol} / 1$ re- spectively, and the corresponding portal-arterial differences averaged 343,380 and $493 \mu \mathrm{mol} / 1$. Thus there was a trend, though not significant $(P>0.10)$, for portal concentrations and portal-arterial differences of propionate to increase as the volatile fatty acid concentration of the test solutions was increased.

Blood propionate concentrations were correlated with propionate absorption rates (Table 1). The correlation coefficients were $0.91 \quad(P<0.001)$ for portal blood, $0.67(P<0.01)$ for arterial blood, and $0.69(P<0.05)$ for the portal-arterial differences. Arterial propionate concentrations, which averaged $64 \mu \mathrm{mol} / 1$ and ranged from 26 to $127 \mu \mathrm{mol} / 1$, tended to be higher in experiments with faster rates of propionate absorption.

Lactate concentrations for the ten experiments averaged $480 \mu \mathrm{mol} / 1$ in portal blood, a value about $75 \mu \mathrm{mol} / 1 \mathrm{higher}$ than that in arterial blood. Unlike propionate, the concentrations of lactate in blood apparently did not vary in response to $\mathrm{pH}$ and volatile fatty acid concentration of the test solutions. The correlations between propionate absorption rates (Table 1) and lactate concentrations (Table 2) in portal $(r=0.52)$ and arterial $(r=0.47)$ blood and

Table 2. Concentration and distribution of propionate and lactate in blood during absorption of volatile fatty acids from the ruminoreticulum of calves

Information about total volatile fatty acids is given in Table 1 and analytical procedures are described in detail in the text. Each value represents the mean of six observations taken between 5 and $45 \mathrm{~min}$ after propionate administration except for Expt. 3 with only five observations.

\begin{tabular}{|c|c|c|c|c|c|c|c|c|}
\hline \multirow[b]{3}{*}{$\begin{array}{l}\text { Expt. } \\
\text { group }\end{array}$} & \multicolumn{2}{|c|}{ Test solution } & \multirow[b]{3}{*}{$\begin{array}{c}\text { Expt. } \\
\text { no. }\end{array}$} & \multirow{2}{*}{\multicolumn{2}{|c|}{$\begin{array}{c}\begin{array}{c}\text { Propionate } \\
\text { concn. }(\mu \mathrm{mol} / \mathrm{l})\end{array} \\
\underbrace{2}\end{array}$}} & \multirow{2}{*}{\multicolumn{2}{|c|}{$\begin{array}{c}\begin{array}{c}\text { Lactate } \\
\text { concn. }(\mu \mathrm{mol} / 1)\end{array} \\
\end{array}$}} & \multirow{3}{*}{$\begin{array}{l}\begin{array}{c}\text { Lactate contribution } \\
\text { to total propionate } \\
\text { plus lactate }\end{array} \\
\begin{array}{l}\text { Portal-arterial } \\
\text { difference }(\%)\end{array}\end{array}$} \\
\hline & \multirow{2}{*}{\multicolumn{2}{|c|}{ 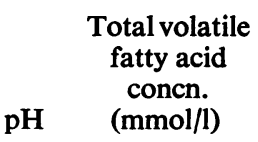 }} & & & & & & \\
\hline & & & & Portal & $\begin{array}{l}\text { Portal-arterial } \\
\text { difference }\end{array}$ & Portal & $\begin{array}{l}\text { Portal-arterial } \\
\text { difference }\end{array}$ & \\
\hline $\mathbf{a}$ & 7.2 & 150 & $\begin{array}{l}2 \\
3 \\
\text { Averag }\end{array}$ & $\begin{array}{r}333 \\
412 \\
\text { ge } 373\end{array}$ & $\begin{array}{l}307 \\
382 \\
345\end{array}$ & $\begin{array}{l}466 \\
517 \\
492\end{array}$ & $\begin{array}{r}94 \\
123 \\
109\end{array}$ & $\begin{array}{l}23.8 \\
23.4 \\
23.6\end{array}$ \\
\hline b & 4.8 & 150 & $\begin{array}{l}1 \\
4 \\
\text { Averag }\end{array}$ & $\begin{array}{r}691 \\
837 \\
\text { ge } 764\end{array}$ & $\begin{array}{l}622 \\
718 \\
670\end{array}$ & $\begin{array}{l}443 \\
556 \\
500\end{array}$ & $\begin{array}{l}86 \\
93 \\
90\end{array}$ & $\begin{array}{l}12.3 \\
11.5 \\
11.9\end{array}$ \\
\hline \multicolumn{4}{|c|}{$\begin{array}{l}\text { Significance of difference between corre- } \\
\text { sponding averages of groups a and } b \text {. }\end{array}$} & $\begin{array}{c}P= \\
0.05-0.10\end{array}$ & $P=0.01-0.05$ & $P>0.10$ & $P>0.10$ & $P=0.001-0.01$ \\
\hline c & 6.0 & 75 & $\begin{array}{l}6 \\
8 \\
\text { Averag }\end{array}$ & $\begin{array}{r}315 \\
464 \\
\text { ge } 390\end{array}$ & $\begin{array}{l}282 \\
404 \\
343\end{array}$ & $\begin{array}{l}380 \\
438 \\
409\end{array}$ & $\begin{array}{l}63 \\
75 \\
69\end{array}$ & $\begin{array}{l}18.4 \\
16.2 \\
17.3\end{array}$ \\
\hline d & 6.0 & 150 & $\begin{array}{l}5 \\
9 \\
\text { Averag }\end{array}$ & $\begin{array}{r}448 \\
457 \\
\text { ge } 453\end{array}$ & $\begin{array}{l}394 \\
365 \\
380\end{array}$ & $\begin{array}{l}598 \\
555 \\
577\end{array}$ & $\begin{array}{l}72 \\
47 \\
60\end{array}$ & $\begin{array}{l}15.2 \\
11.4 \\
13.3\end{array}$ \\
\hline e & 6.0 & 225 & $\begin{array}{l}7 \\
10 \\
\text { Averag }\end{array}$ & $\begin{array}{r}573 \\
571 \\
\text { ge } 572\end{array}$ & $\begin{array}{l}446 \\
540 \\
493\end{array}$ & $\begin{array}{l}518 \\
324 \\
421\end{array}$ & $\begin{array}{l}56 \\
45 \\
51\end{array}$ & $\begin{array}{r}11.6 \\
7.8 \\
9.7\end{array}$ \\
\hline Signific & ce of & lifference betw & en corre- & $P>0.10$ & $P>0.10$ & $P>0.10$ & $P>0.10$ & $P=0.01-0.05$ \\
\hline
\end{tabular}


also the portal-arterial differences $(r=0.26)$ were low and not significant. Portal-arterial differences in propionate and lactate were not correlated with each other $(r=0.09)$.

The contribution of lactate to the total propionate plus lactate portal-arterial concentration differences (Table 2) averaged $15.2 \%$ for the ten experiments, but was lower at pH4.8 than at pH7.2 $(P<0.01)$ and decreased as the volatile fatty acid concentration of the test solutions increased $(P<0.05)$. These concentration differences represent the maximum values for conversion of propionate into lactate, unless some lactate is oxidized by gastrointestinal tissues.

Results on the concentrations of propionate and lactate in blood are inconclusive with respect to the conversion of propionate into lactate because lactate entering the portal circulation does not necessarily originate from propionate. The contributions of lactate to the portal-arterial concentration differences in propionate plus lactate (Table 2) would represent the extents of propionate conversion into lactate only if lactate were the sole metabolite produced from propionate during absorption from the ruminoreticulum and if lactate were not produced from precursors other than propionate.

\section{Radioactivity associated with propionate and lactate}

Regression analysis showed that total radioactivity increased by an average of about 43 d.p.m./ $\mathrm{ml}$ per min in both portal and arterial blood $(P<0.001)$ during the ten experiments. The radioactivity associated with lactate in portal and arterial blood, expressed as d.p.m./ml of blood, also increased during the trials $(P<0.001)$, but the radioactivity associated with propionate was constant. These trends reflect continual and constant absorption of $\left[2-{ }^{14} \mathrm{C}\right]$ propionate and transfer of label into lactate. The portal-arterial differences in total radioactivity of blood and also in radioactivity associated with propionate plus lactate did not exhibit any significant trends with time, indicating fairly uniform entry of radioactivity.

The contribution of radioactivity associated with propionate plus lactate to total radioactivities of blood was calculated (Table 3). Mean percentages ranged from 23.6 to $37.6 \%$ in portal blood and from 2.2 to $8.8 \%$ in arterial blood. The percentage of total blood radioactivity associated with propionate plus lactate decreased during the experiments indicating that blood constituents other than propionate and lactate accounted for increasingly more of the radioactivity in peripheral blood.

The contribution of propionate plus lactate to the portal-arterial differences in total radioactivity, however, was about $100 \%$ or above for all five test solutions (Table 3), and the percentages for any one experiment did not show that trends increased or decreased with time. Though the observed percentages generally exceed the theoretical maximum of $100 \%$, within experimental limits their agreement is reasonable. Concentrations of propionate and lactate could be corrected for recovery, but the total radioactivity in blood could not be corrected.

Propionate plus lactate accounted for $100 \%$ or more of the portal-arterial differences in total radioactivity, suggesting strongly that most, if not all, of the propionate absorbed from the ruminoreticulum was transported into the portal system as propionate or lactate and that, consequently, the conversion into products other than lactate was either very small or absent.

Table 3. Contribution of $\left[{ }^{14} \mathrm{C}\right]$ propionate plus $\left[{ }^{14} \mathrm{C}\right]$ lactate to total radioactivity of blood after administration of $\left[2-{ }^{14}\right.$ C]propionate into the ruminoreticulum of calves

Details of test solutions administered are shown in Table 1. The determination of total blood radioactivity and of the radioactivity of propionate and lactate are described in the text. The values reported are the means \pm S.E.M. of two experiments on the same test solutions of volatile fatty acids.

Contribution of radioactive propionate

Test solution

\begin{tabular}{cc}
\hline & $\begin{array}{c}\text { Total volatile } \\
\text { fatty acid concn. } \\
\text { pH }\end{array}$ \\
7.2 & 150 \\
4.8 & 150 \\
6.0 & 75 \\
6.0 & 150 \\
6.0 & 225
\end{tabular}

Expt. no.
2,3
1,4
6,8
5,9
7,10
plus lactate to total blood radioactivity

$\begin{array}{ccc}\begin{array}{c}\text { Portal } \\ (\%)\end{array} & \begin{array}{c}\text { Arterial } \\ (\%)\end{array} & \begin{array}{c}\text { Portal-arterial } \\ \text { difference } \\ (\%)\end{array} \\ 23.6 \pm 3.4 & 2.2 \pm 0.2 & 109.7 \pm 9.4 \\ 34.4 \pm 4.4 & 5.3 \pm 1.2 & 101.3 \pm 4.5 \\ 30.1 \pm 4.4 & 5.7 \pm 0.5 & 115.6 \pm 11.1 \\ 33.6 \pm 5.8 & 8.8 \pm 1.5 & 113.0 \pm 3.8 \\ 37.6 \pm 6.0 & 6.8 \pm 1.2 & 116.4 \pm 4.4\end{array}$

Vol. 126 


\section{Extent of propionate conversion into lactate}

Table 4 is a summary of contributions of radioactive lactate to the total radioactivity associated with propionate plus lactate in blood. That lactate accounted for more radioactivity in arterial than in portal blood can be explained by the removal of relatively more propionate by the liver. During each experiment, the contribution of lactate increased with time in both portal and arterial blood, largely due to a rising specific radioactivity of lactate.

The specific radioactivity of lactate was always higher in portal than in the corresponding arterial blood. This, along with positive portal-arterial differences in lactate concentration, indicated that lactate was produced in the portal-drained viscera. The extent of conversion was estimated by the contribution of lactate to the portal-arterial differences in radioactivity associated with propionate plus lactate (Table 4). More propionate appeared to be converted into lactate when the $\mathrm{pH}$ of the test solutions was 7.2 rather than 4.8. Volatile fatty acid concentration also affected the conversion into lactate $(P<0.05)$, which decreased from an average of $7.0 \%$ at $75 \mathrm{mmol} / 1$ to $2.7 \%$ at $225 \mathrm{mmol} / 1$.

Regression analysis revealed a trend (Fig. 1, Expts. 1 and 2) for the calculated extent of propionate conversion to increase with time. Average regression coefficients calculated and expressed in percentage/ $5 \mathrm{~min}$ were 1.24 and 0.37 for test solutions of $\mathrm{pH} 7.2$ and 4.8 respectively, and $0.76,0.51$ and 0.22 for test solutions of 75,150 and $225 \mathrm{mmol} / 1$ of total volatile fatty acids respectively. The regression coefficients were obviously higher with experiments in which absorption of volatile fatty acid was slower.

There is an apparent discrepancy in that the extent of propionate conversion into lactate calculated from portal-arterial concentration differences (Table 2)

Table 4. Contribution of radioactive lactate to the radioactivity associated with propionate plus lactate and the extent of propionate conversion into lactate

Details of test solutions administered are in Table 1. The contributions of lactate to the portal-arterial differences in radioactivity of propionate plus lactate are listed in the last column and define the extent of propionate conversion into lactate during absorption. Each value is the mean of six observations taken between 5 and $45 \mathrm{~min}$ after propionate administration except for Expt. 3 with only five observations.

\begin{tabular}{|c|c|c|c|c|c|c|}
\hline \multirow[b]{2}{*}{$\begin{array}{l}\text { Expt. } \\
\text { group }\end{array}$} & \multicolumn{2}{|c|}{ Test solution } & \multicolumn{3}{|c|}{$\begin{array}{l}\text { Contribution of lactate to } \\
\text { propionate plus lactate } \\
\text { radioactivity }\end{array}$} & \multirow{2}{*}{$\begin{array}{c}\text { Propionate converted } \\
\text { into lactate } \\
\text { during absorption } \\
(\%)\end{array}$} \\
\hline & $\mathrm{pH}$ & $\begin{array}{l}\text { Total volatile } \\
\text { fatty acid concn. } \\
(\mathrm{mmol} / \mathrm{l})\end{array}$ & Expt. no. & $\begin{array}{l}\text { Portal } \\
\text { blood } \\
(\%)\end{array}$ & $\begin{array}{l}\text { Arterial } \\
\text { blood } \\
(\%)\end{array}$ & \\
\hline $\mathbf{a}$ & 7.2 & 150 & $\begin{array}{l}2 \\
3\end{array}$ & $\begin{array}{r}15.1 \\
11.0 \\
\text { Ige } 13.1\end{array}$ & $\begin{array}{l}64.9 \\
60.0 \\
62.5\end{array}$ & $\begin{array}{l}9.1 \\
6.3 \\
7.7\end{array}$ \\
\hline \multirow[t]{2}{*}{ b } & 4.8 & 150 & $\begin{array}{l}1 \\
4\end{array}$ & $\begin{array}{r}7.3 \\
6.7 \\
\text { lge } 7.0\end{array}$ & $\begin{array}{l}49.2 \\
35.0 \\
42.1\end{array}$ & $\begin{array}{l}3.4 \\
2.5 \\
3.0\end{array}$ \\
\hline & \multicolumn{3}{|c|}{$\begin{array}{l}\text { Significance of differences between corre- } \\
\text { sponding averages of groups } a \text { and } b \text {. }\end{array}$} & $P>0.10$ & $P>0.10$ & $P>0.10$ \\
\hline c & 6.0 & 75 & $\begin{array}{l}6 \\
8\end{array}$ & $\begin{array}{r}16.7 \\
15.3 \\
\text { tge } 16.0\end{array}$ & $\begin{array}{l}64.1 \\
57.5 \\
60.8\end{array}$ & $\begin{array}{l}6.7 \\
7.3 \\
7.0\end{array}$ \\
\hline d & 6.0 & 150 & $\begin{array}{l}5 \\
9\end{array}$ & $\begin{array}{r}13.2 \\
12.9 \\
\text { Ige } 13.1\end{array}$ & $\begin{array}{l}53.9 \\
43.2 \\
48.6\end{array}$ & $\begin{array}{l}4.5 \\
3.6 \\
4.1\end{array}$ \\
\hline e & 6.0 & 225 & $\begin{array}{r}7 \\
10\end{array}$ & $\begin{array}{r}10.6 \\
4.9 \\
\text { lge } 7.8\end{array}$ & $\begin{array}{l}32.7 \\
46.9 \\
39.8\end{array}$ & $\begin{array}{l}2.8 \\
2.6 \\
2.7\end{array}$ \\
\hline & Sign & cance of differenc & tween corre- & $P>0.10$ & $P>0.10$ & $P<0.05$ \\
\hline
\end{tabular}
sponding averages of groups $c, d$ and $e$. 
was 2.2-4.6 times higher than that calculated from portal-arterial differences in radioactivity (Table 4). A possible explanation is that unlabelled lactate may have entered the portal vein or propionate was converted into other metabolites. The diet fed to the

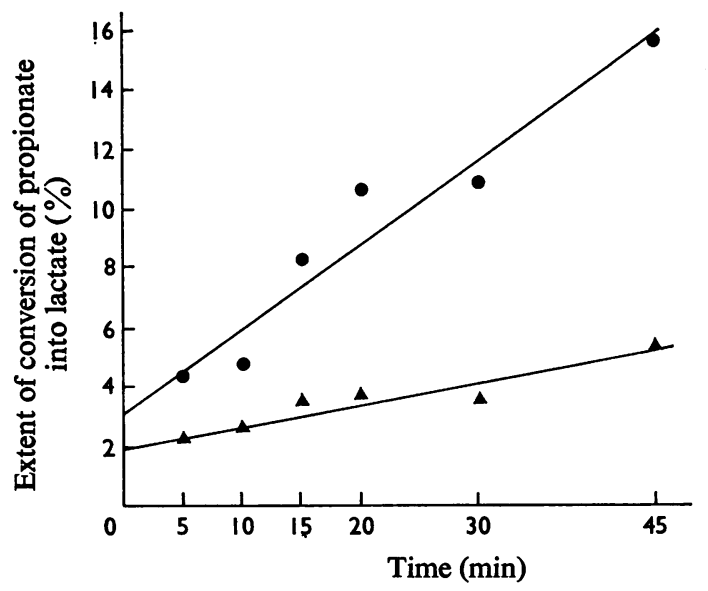

Fig. 1. Conversion of propionate into lactate

The change in the extent of conversion of propionate into lactate with time was measured after placing radioactive propionate into the ruminoreticulum of calves. $\triangle$, Expt. 1, test solution pH4.8; $\bullet, 2$, pH7.2. calves is unlikely to have allowed significant amounts of lactic acid to pass from the ruminoreticulum to the small intestine (Mackenzie, 1967) and so become available for absorption during the experiments. Test solutions were free of lactic acid at the end of experiments. It is unlikely that propionate was converted extensively into metabolites other than lactate by the epithelium because propionate and lactate could account for the entire portal-arterial difference in total radioactivity of blood (Table 3 ). If a portion of propionate was oxidized to $\mathrm{CO}_{2}$, however, it would not be detected. This explanation does not appear to be consistent with the results.

A second explanation for the observed discrepancy might be that propionate label was lost in the tricarboxylic acid cycle before lactate was formed. In forestomach epithelium propionate is converted into lactate via succinate, a symmetrical $\mathrm{C}_{4}$ intermediate of the tricarboxylic acid cycle (Pennington \& Sutherland, 1956). Annison et al. (1963) found that the incorporation of $\mathrm{C}-2$ of propionate into $\mathrm{C}-3$ and $\mathrm{C}-4$ relative to $\mathrm{C}-1, \mathrm{C}-2, \mathrm{C}-5$ and $\mathrm{C}-6$ of glucose was fairly low after intraportal infusion of $\left[2-{ }^{14} \mathrm{C}\right]-$ propionate in sheep. This indicates that, in the metabolism of propionate via succinate, the extent of equilibration of ${ }^{14} \mathrm{C}$ in the tricarboxylic acid cycle may be small, at least in the conversion into glucose in the liver of sheep. Thus loss of radioactivity by tricarboxylic acid cycle activity is unlikely to explain the discrepancy.

A third possible explanation, the formation of

Table 5. Portal glucose concentrations and portal-arterial differences in glucose and lactate during absorption of volatile fatty acids from the ruminoreticulum of calves

Portal and arterial glucose concentrations were determined on selected samples from Expts. 3-10.

Test solution

\begin{tabular}{cccc}
\hline & $\begin{array}{c}\text { Total volatile } \\
\text { fatty acid concn. } \\
\text { pH }\end{array}$ & Expt. no. & $\begin{array}{c}\text { Sampling } \\
\text { time } \\
(\mathrm{min})\end{array}$ \\
7.2 & 150 & 3 & 10 \\
& & & 30 \\
4.8 & 150 & 4 & 45 \\
& & & 5 \\
6.0 & 75 & 6 & 30 \\
& & & 45 \\
6.0 & 150 & 5 & 10 \\
& & 5 & 15 \\
& & 9 & 30 \\
6.0 & 225 & 7 & 5 \\
& & 10 & 30 \\
& & & 5 \\
& & &
\end{tabular}

Portal glucose concn. (mg/100ml)

\section{7}

52.1

57.8

46.1

41.5

48.8

54.2

55.7

53.0

50.6

51.7

49.2

46.1

51.3

52.5
Portal-arterial concentration differences

$\overbrace{\begin{array}{c}\text { Glucose } \\ (\mu \mathrm{mol} / \mathrm{l})\end{array}}^{\begin{array}{c}\text { Lactate } \\ (\mu \mathrm{mol} / \mathrm{l})\end{array}}$

$\begin{array}{rr}-302 & 188 \\ -48 & 93 \\ -132 & 163 \\ -9 & 88 \\ -37 & 99 \\ -47 & 103 \\ -16 & 67 \\ -13 & 74 \\ -82 & 94 \\ -18 & 104 \\ -51 & 51 \\ -39 & 68 \\ -63 & 67 \\ -31 & 40 \\ -104 & 54\end{array}$


Table 6. Specific and total radioactivity of blood glucose and lactate in arterial and portal blood of calves absorbing volatile fatty acids from the rumen

Specific radioactivity of glucose and lactate in selected samples from Expts. 3, 4 and 8-10 are shown.

\begin{tabular}{|c|c|c|c|c|c|c|c|}
\hline & rest solution & & & $\begin{array}{r}\text { Specific } \\
\text { radioactivity (d.p }\end{array}$ & $\mathrm{n} . / \mu \mathrm{mol})$ & & \\
\hline & Total volatile & & Sampling & Combined portal & & total radioa & (d.p.m./ml \\
\hline pH & $(\mathrm{mmol} / \mathrm{l})$ & Expt. no. & (min) & glucose & lactate & Glucose & Lactate \\
\hline 7.2 & 150 & 3 & $\begin{array}{l}10 \\
30\end{array}$ & $\begin{array}{l}426 \\
927\end{array}$ & $\begin{array}{r}44 \\
163\end{array}$ & $\begin{array}{r}-129 \\
-44\end{array}$ & $\begin{array}{l}46 \\
60\end{array}$ \\
\hline & & & 45 & 1311 & 230 & -173 & 98 \\
\hline 4.8 & 150 & 4 & 5 & 669 & 117 & -6 & 17 \\
\hline & & & 30 & 1509 & 197 & -55 & 38 \\
\hline & & & 45 & 3581 & 319 & -169 & 55 \\
\hline 6.0 & 75 & 8 & 10 & 299 & 121 & -149 & 28 \\
\hline & & & 15 & 816 & 140 & -67 & 45 \\
\hline 6.0 & 150 & 9 & 5 & 86 & 33 & -4 & 5 \\
\hline & & & 45 & 1041 & 148 & -40 & 25 \\
\hline 6.0 & 225 & 10 & 5 & 93 & 11 & -3 & 6 \\
\hline & & & 20 & 422 & 37 & -44 & 12 \\
\hline
\end{tabular}

lactate from glucose by glycolytic activity of gastrointestinal tissues (Srivastava \& Hübscher, 1966), is supported by subsequent results. The possible contribution of gastrointestinal glucose metabolism to the portal-arterial differences of lactate was estimated. Since this was not planned for in the original design of the experiments sufficient amounts of protein-free blood filtrates were not available for glucose analysis of all samples. Portal and arterial glucose concentrations were determined and, by assuming that glucose was neither absorbed nor synthesized by the portaldrained viscera, corresponding portal and arterial blood filtrates still available were combined and analysed for glucose radioactivity. Representative results are presented in Tables 5 and 6. The portalarterial differences in glucose concentrations (Table 5) were consistently negative, indicating gastrointestinal utilization of glucose (Bensadoun \& Ichhponani, 1968; Bergman et al., 1970; Katz \& Bergman, 1969; Roe et al., 1966). If one molecule of glucose is converted into two molecules of lactate, the observed portal-arterial differences in glucose could usually account for much or all of the corresponding positive portal-arterial differences in lactate (Table 5). Roe et al. (1966) made a similar observation in non-pregnant sheep.

The specific radioactivity of circulating glucose was much higher than that of arterial lactate (Table 6). Thus, as circulating glucose is converted into lactate by glycolytic activity of gastrointestinal tissues, the specific radioactivity of portal lactate will increase. The specific radioactivity of glucose increased faster during the experiments than did that of arterial lactate. A comparison of the portal-arterial differences of total radioactivity in glucose with those in lactate (Table 6) showed that glucose could account for a large part or all of the radioactive lactate entering the portal circulation from gastrointestinal tissues. Thus, to the extent that glucose utilized by gastrointestinal tissues was converted into lactate, the percentage contributions of lactate to the portal-arterial differences presented in Tables 2 and 4 will overestimate the actual extent of propionate conversion into lactate. Glucose could often account for the entire portal-arterial differences in radioactivity and concentration of lactate (Tables 5 and 6).

It is therefore concluded that the apparent increase in the percentage metabolism of propionate during the experiments can be attributed entirely to lactate production from increasingly labelled glucose rather than to direct conversion from propionate. Since the percentages of propionate metabolism of Table 4 are means of all observations obtained per experiment, they overestimate the true extent of metabolism by the epithelium of the ruminoreticulum. From linear regression equations relating percentage metabolism to time, the extent of propionate conversion was extrapolated to 'zero-time' and averaged $2.3 \%$, with a range of $1.0-4.6 \%$ for the ten experiments. The 'zero-time' percentages are inversely correlated with the rates of propionate absorption $(P<0.01)$; i.e. the faster the propionate was absorbed, the lower was the relative extent to which its was converted into lactate by the epithelium of the 
ruminoreticulum. The amount of radioactive lactate produced was approximately the same in most experiments.

The important conclusion to be drawn from our study is that the direct conversion of propionate into lactate by the ruminoreticulum epithelium was quite small, probably less than $5 \%$ as estimated by the extrapolated 'zero-time' percentages. Cook \& Miller (1965) also concluded that propionate is absorbed from the rumen of sheep and goats largely as such, and presented to the liver for metabolism. Because the magnitude of conversion of propionate into lactate was within a very narrow range, even when solutions of quite variable total volatile fatty acids concentration were used, it seems unlikely that our conclusions would be different with fed animals. However, the total absorption rate might be greater, because of greater epithelial exposure, in normal fully fed animals.

Leng et al. (1967), who infused radioactive propionate into the rumen of sheep, estimated that up to $70 \%$ of the propionate was metabolized first to lactate before it was converted into glucose and suggested that the rumen epithelium was the site of this seemingly extensive conversion of propionate into lactate. This does not agree with our results, which show that propionate enters the portal vein from the ruminoreticulum, with only minor or possibly no conversion into lactate. Because Leng et al. (1967) analysed only blood from the jugular vein, they failed to provide direct proof for their proposal that the rumen epithelium was the site of propionate metabolism to lactate. In the present work, the specific radioactivity of circulating glucose was higher than that of arterial lactate, and we therefore conclude that the majority of propionate reaching the liver was synthesized to glucose before it was converted into lactate.

This is Journal Paper no. J-6859 of the Iowa Agriculture and Home Economics Experiment Station, Ames, Iowa (Project nos. 1671 and 1324). The work was supported in part by funds provided by Grants AM-10706 and HE04969, U.S. Department of Health, Education and Welfare. Technical assistance in various phases of the work by Mrs. Marlene Richard, Mrs. Ann Zimmerli and Mr. Paul Wangsness is gratefully acknowledged. Results in this paper are from a dissertation submitted to Iowa State University by $\mathrm{E}$. W. in partial fulfillment of the requirements for the Ph.D. degree.

\section{References}

Annison, E. F., Leng, R. A., Lindsay, D. B. \& White, R. R. (1963) Biochem. J. 88, 248

Ash, R. W. (1962) Anim. Prod. 4, 309

Bensadoun, A. \& Ichhponani, J. S. (1968) Proc. Cornell Nutr. Conf. Feed Mfrs. p. 115

Bergman, E. N., Katz, M. L. \& Kaufman, C. F. (1970) Amer. J. Physiol. 219, 785

Brown, G. F., Armstrong, D. G. \& MacRae, J. C. (1968) Brit. Vet.J. 124, 78

Bruno, G. A. \& Christian, J. E. (1961) Anal. Chem. 33, 1216

Casjens, S. R. \& Morris, A. J. (1965) Biochim. Biophys. Acta 108, 677

Conner, G. H. \& Fries, G. F. (1960) Amer. J. Vet. Res. 21, 1028

Cook, R. M. \& Miller, L. D. (1965) J. Dairy Sci. 48, 1339

Dougherty, R. W. (1955) Cornell Vet. 45, 331

Folin, O. \& Wu, H. (1919) J. Biol. Chem. 38, 81

Guyton, A. C. (1966) Textbook of Medical Physiology, 3rd ed., p. 426, W. B. Saunders Co., Philadelphia

Hohorst, H.-J. (1965) in Methods of Enzymatic Analysis (Bergmeyer, H.-U., ed.), p. 266, Academic Press, New York

Jones, G. B. (1965) Anal. Biochem. 12, 249

Katz, M. L. \& Bergman, E. N. (1969) Amer.J.Physiol. 216, 953

Leng, R. A., Steel, J. W. \& Luick, J. R. (1967) Biochem. J. 103, 785

Mackenzie, D. D. S. (1967) J. Dairy Sci. 50, 1772

Malawer, S. J. \& Powell, D. W. (1967) Gastroenterology 53,250

McGilliard, A. D. (1971) J. Appl. Physiol. 30, 297

Olsen, J. D., Dougherty, R. W. \& Bond, K. (1967) Cornell Vet. 57, 171

Pennington, R. J. \& Sutherland, T. M. (1956) Biochem. J. 63, 618

Ramsey, H. A. (1963) J. Dairy Sci. 46, 480

Roe, W. E., Bergman, E. N. \& Kon, K. (1966) Amer. J. Vet. Res. 27,729

Srivastava, L. M. \& Hübscher, G. (1966) Biochem. J. 100, 458

Steel, R. G. D. \& Torrie, J. H. (1960) Principles and Procedures of Statistics, McGraw-Hill Book Co. New York

Sutton, J. D., McGilliard, A. D. \& Jacobson, N. L. (1963) J. Dairy Sci. 46, 426

Taylor, T. A. \& Ramsey, H. A. (1965) J. Dairy Sci. 48, 505

van Kampen, E. J. \& Zijlstra, W. G. (1961) Clin. Chim. Acta 6, 538

Weigand, E., Young, J. W. \& Jacobson, N. L. (1967) J. Dairy Sci. 50, 1003 (Abstr.) 